\title{
Desain Alat Pembakaran untuk Pedagang Olahan Ikan Menggunakan Analisis Pengukuran RULA (Rapid Upper Limb Assesment)
}

\author{
${ }^{1}$ Nasir Widha Setyanto, ${ }^{2}$ Ishardita Pambudi Tama, ${ }^{3}$ Ratih Ardia Sari, ${ }^{4}$ Rio Prasetyo Lukodono, \\ ${ }^{5}$ Raditya Ardianwiliandri \\ 1, 2, 3, 4, 5urusan Teknik Industri Universitas Brawijaya Malang \\ Jl. MT. Haryono 167 Malang, 65145 \\ ${ }^{1} N a z z y r \_l i n @ u b . a c . i d,{ }^{2}$ kangdith@ub.ac.id, ${ }^{3}$ rath_ardia@ub.ac.id, ${ }^{4}$ rio_pl@ub.ac.id, \\ ${ }^{5}$ raditya_ti_ub@ub.ac.id
}

\begin{abstract}
ABSTRAK
Komoditas utama yang diperdagangkan diperdagangkan di pantai Pelang adalah hasil laut terutama ikan. Ikan dijual dalam berbagai kondisi seperti mentah, olahan setengah jadi, maupun dalam kondisi siap saji. Pada pantai pelang banyak masyarakat yang membuka usaha untuk berjualan olahan dari ikan seperti ikan bakar. Masyarakat menjual ikan bakar dengan cara konvensional yaitu dibakar di atas panggangan sederhana dengan cara dikipas menggunakan tenaga manusia. Proses memasak yang dilakukan adalah masih sederhana yaitu dengan membolak-balik ikan di atas panggangan. Banyak resiko yang didapatkan oleh pedagang ikan ketika memasak dengan proses membakar secara konvensional seperti adanya ancama luka bakar, produk kurang higienis, asap mengganggu pernafasan, dan lain sebagainya. Dibutuhkan suatu penelitian yang berkaitan dengan desain alat pengasapan sehingga dapat meminimalisisr resiko yang muncul dari adanya proses pembakaran. Langkah yang dilakukan untuk mendesain alat pembakaran ikan adalah dengan menganalisis permasalahan dengan Nordic body map yang kemudian dilakukan analisis postur dengan metode RULA. Untuk desain perbaikan alat pembakaran menggunakan dasar dimensi antorpometri. Hasil dari perbaikan desain alat pembakaran adalah penurunan nilai skor RULA yang mengindikasikan resiko cedera mengalami penurunan potensi.
\end{abstract}

Kata kunci: Alat Pembakaran Ikan, Antropometri, Nordic Body Map, RULA.

\section{Grill Tools Design for Fish Food Seller Using RULA (Rapid Upper Limb Assesment) Measurement Analysis}

\begin{abstract}
The main commodities traded on the Pelang beach are sea products, especially fish. Fish is sold in a variety of conditions such as raw, semi-processed, and ready-to-eat conditions. On Pelang beach, many people open businesses to sell processed fish such as grilled fish. The community conventionally sells grilled fish, which is burned on a simple grill using a fan and human power. The cooking process is still simple, by flipping fish on the grill. Many risks are obtained when cooking with conventional burning processes such as the threat of burns, less hygienic products, smoke interferes with breathing. Research related to the design of grill equipment is needed to minimize the risk from the grilling process. The steps are taken to design a fish grilling tool is to analyze the problem with the Nordic body map, then posture analysis using the RULA method. For the design of improvements to the grilling tool using the basic dimensions of anthropometry. The result of the improved design of the combustion device is a decrease in the value of the RULA score which indicates the risk of injury.
\end{abstract}

Keywords: Fish Grilling Tools, Antrophometry, Nordic Body Map, RULA. 


\section{Pendahuluan}

Teknologi akan membantu pekerjaan dari manusia menjadi lebih mudah. Teknologi diciptakan oleh manusia dalam rangka meningkatkan kinerja dari manusia, mengurangi dampak negatif yang akan diterima manusia. Berdasarkan latar belakang tersebut perkembangan teknologi menjadi semakin pesat dalam menghasilkan piranti atau alat-alat yang dapat membantu atau bahkan menggantikan dari pekerjaan manusia. Dengan mengingat pekerjaan yang banyak dan semakin dinamisnya yang dikerjakan oleh manusia tetapi belum dirasakan oleh berbagai sektor. Sebagai contoh pada sektor yang memanfaatkan energi atau aktivitas yang bersifat konvensional. Sebagai contoh aktivitas yang bersifat konvensional adalah aktivitas yang dilakukan di daerah pelosok yang belum terjangkau teknologi secara optimal. Sebagai contoh untuk usaha-usahs di daerah pelosok seperti pengusaha ikan bakar, ternak ikan, ternak ayam, dan lain-lain.

Pengusaha pada bidang kuliner merupakan sebuah bisnis yang menjanjikan. Bidang kuliner merupakan kebutuhan dasar dari setiap manusia yaitu kebutuhan akan makanan. Ditunjang lagi kondisi geografis Indonesia yang subur dan kaya akan hasil laut menunjang untuk dilakukannya bisnis kuliner. Di Indonesia juga ditunjang dengan banyaknya pantai yang dapat dijadikan sebagai tempat rekreasi. Hal sangat baik sekali dengan melihat Indonesia banyak penduduk yang sibuk bekerja yang memiliki tingkat stres yang tinggi.

Pantai Pelang merupakan salah satu destinasi wisata di kabupaten Trenggalek. Pantai pelang terletak di desa Wonocoyo, kecamatan Panggul, kabupaten Trenggalek, Jawa Timur. Jarak dari pusat kota Trenggalek ke arah barat daya sejauh $57 \mathrm{~km}$. Lokasi Pantai Pelang berada di sebelah barat kabupaten Trenggalek yang dekat dengan perbatasan kabupaten Pacitan. Rute dari pusat kota Trenggalek ke arah barat daya menuju kecamatan Panggul.

Komoditas utama yang diperdagangkan diperdagangkan di pantai Pelang adalah hasil laut terutama ikan. Ikan dijual dalam berbagai kondisi seperti mentah, olahan setengah jadi, maupun dalam kondisi siap saji. Pada pantai pelang banyak masyarakat yang membuka usaha untuk berjualan olahan dari ikan seperti ikan bakar. Masyarakat menjual ikan bakar dengan cara konvensional yaitu dibakar di atas panggangan sederhana dengan cara dikipas menggunakan tenaga manusia. Proses memasak yang dilakukan adalah masih sederhana yaitu dengan membolak-balik ikan di atas panggangan. Banyak resiko yang didapatkan oleh pedagang ikan ketika memasak dengan proses membakar secara konvensional seperti adanya ancama luka bakar, produk kurang higienis, asap mengganggu pernafasan, dan postur yang tidak ergonomis.

Postur yang tidak ergonomis akan memunculkan adanya keluhan dan berakibat pada terjadinya cedera. Keluhan yang terjadi bias disebabkan oleh beberapa hal diantaranya adalah kelebihan pembebanan pada otot, postur yang tidak sesuai, dan repetitive yang tinggi, sehingga diperlukan adanya identifikasi lebih lanjut (McAtamney \& Corlett, 1993). Beberapa metode dapat dilakukan untuk menganalisis postur kerja pada operator diantaranya adalah OWAS, NIOSH, RULA, OCRA, REBA, LUBA, dan EAWS (Roman-Liu, 2014). RULA adalah analisis yang digunakan secara luas dalam menganalisis postur kerja yang tidak tepat, seperti postur kerja anak-anak di bangku sekolah, postur anak-anak yang dalam menggunakan computer (Sari dan Swara, 2014), (Manghisi dkk, 2017), (Chen dkk, 2014), (Dockrell dkk., 2012). Analisis RULA akan memiliki keandalan ketika dilakukan oleh seorang peneliti yang sama (Dockrell dkk, 2012). RULA berdasarkan aspek yang di analisis akan sesuai pada 
postur kerja yang didominasi oleh tubuh pada bagian atas sebagai contoh pada aktivitas packaging, produksi, dan perkantoran (Ardiliansyah dkk, 2017), (Oesman et al, 2019), (Hardianto et al, 2018). Penerapan lain konsep ergonomi yang dapat memberikan kenyaman pada manusia dalam bekerja juga dapat diaplikasikan pada pada hewan dengan pendekatan berupa zoometri yaitu konsep antropometri pada hewan (Sugiono dkk, 2017).

Berdasarkan kondisi tersebut diperlukan adanya sebuah alat yang secara praktis menyelesaikan permasalahan terebut. Alat-alat panggangan yang dijual disekitar area masyarakat tersebut pun masih bersifat konvensional. Salah satu alasan mengapa hal tersebut terjadi ialah karena akses mereka untuk mendapatkan teknologi untuk proses produksi mereka masih terbatas dan kekurangan untuk modal. Dibutuhkan sebuah inovasi alat panggangan yang sesuai dengan permasalahan yang mereka hadapi. Alat panggangan tersebut diharapkan tidak membutuhkan tenaga yang besar untuk mengipas dan membolak-balikkan ikan sehingga dapat mengoptimalkan kualitas pada proses pembakaran ikan.

\section{Metode Penelitian}

\subsection{Jenis Penelitian}

Penelitian dan pengembangan merupakan suatu proses atau langkahlangkah untuk mengembangkan suatu produk baru atau menyempurnakan produk yang telah ada dan dapat dipertanggungjawabkan. Selain itu, penelitian pengembangan sering dikenal dengan Research and Development (R\&D) adalah metode penelitian yang digunakan untuk menghasilkan produk tertentu, dan menguji keefektifan produk tersebut.

\subsection{Pengumpulan Data}

Pengumpulan data yang dilakukan pada penelitian ini adalah dengan dengan melakukan observasi secara langsung maupun melakukan wawancara secara langsung kepada user yaitu para pedangang ikan asap. Berdasarkan wawancara tersebut akan dapat diketahui kebutuhan dan keinginan user dalam penggunaan alat pemanggang ikan asap.

\subsection{Prosedur Pengembangan}

Pada penelitian pengembangan ini mengacu pada prosedur penelitian pengembangan yang disesuaikan dengan kebutuhan industri pengolahan ikan (Gambar 1).

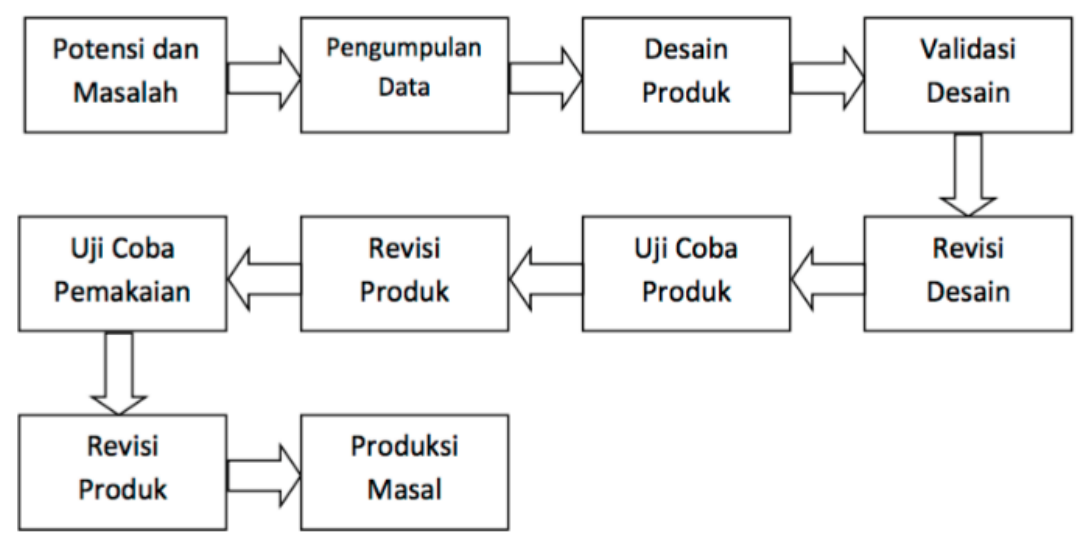

Gambar 1. Prosedur Penelitian Pengembangan Produk Sugiyono (2012: 409) 
Prosedur yang dilakukan dalam penelitian pengembangan ini meliputi beberapa tahap seperti:

1. Potensi dan masalah.

Research and Development $(\mathrm{RnD})$ dapat berawal dari adanya potensi dan masalah. Data tentang potensi dan masalah tidak harus dicari sendiri, tetapi bisa berdasarkan laporan penelitian orang lain atau dokumentasi laporan kegiatan dari perorangan.

2. Pengumpulan data.

Setelah potensi dan masalah dapat ditunjukkan secara faktual, selanjutnya perlu dikumpulkan berbagai informasi yang dapat digunakan sebagai bahan untuk perencanaan.

3. Desain produk.

Hasil akhir dari serangkaian penelitian awal, dapat berupa rancangan kerja baru atau produk baru.

4. Validasi desain.

Proses untuk menilai apakah rancangan kerja baru atau produk baru secara rasional layak digunakan dengan cara meminta penilaian ahli yang berpengalaman.

5. Revisi desain produk.

Produk yang telah didesain kemudian direvisi setelah diketahui kelemahannya.

6. Uji coba produk.

Melakukan uji coba terbatas.

7. Revisi produk.

Produk direvisi berdasarkan hasil uji coba terbatas.

8. Uji coba pemakaian.

Dilakukan uji coba dalam kondisi yang sesungguhnya.

9. Revisi produk.

Apabila ada kekurangan dalam penggunaan pada kondisi sesungguhnya, maka produk diperbaiki.

10. Produksi terbatas.

Demi kepentingan tugas akhir skripsi, pada penelitian pengembangan ini produk yang dihasilkan akan diproduksi secara terbatas.

\section{Hasil dan Pembahasan}

\subsection{Voice of Customer (VOC)}

Pada tahap ini dilakukan pengumpulan data terkait kebutuhan pelanggan berdasarkan pengalaman dari penggunaan alat pembakaran ikan yang selama ini digunakan untuk berproduksi. Pada tahap identifikasi peluang terdapat beberapa tahap studi literatur dan brainstorming terhadap pengguna (kuesioner terbuka). Tahapan tersebut dijelaskan sebagai berikut.

\section{Identifikasi Peluang}

Identifikasi peluang pada penelitian ini yang digunakan adalah melakukan desain ulang alat pembakaran ikan yang selama ini digunakan oleh pedagang ikan di pantai Konang Kabupaten Trenggalek. Menurut pengamatan awal peneliti alat yang saat ini digunakan masih menggunakan bahan bakar arang dan untuk menghidupkan apinya adalah harus selalu dilakukan pengipasan. Tingkat higienis ikan juga dirasa kurang dikarenakan ikan juga akan terkontaminasi oleh serbuk arang bekas pembakaran. Proses yang dilakukan untuk pembakaran ikan adalah antara 15 hingga 20 menit (Gambar 2).

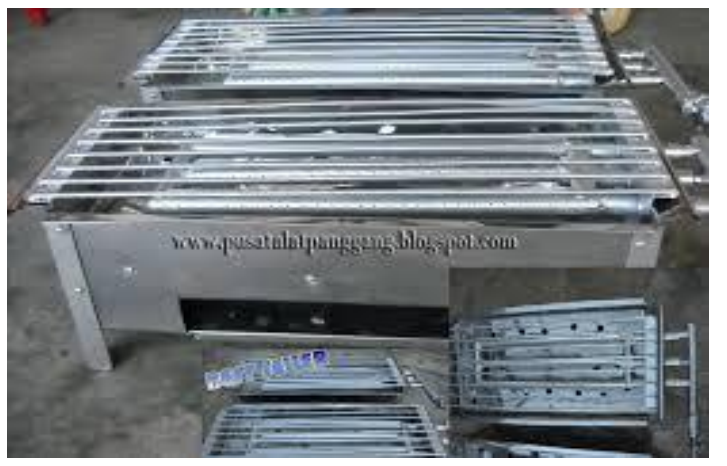

Gambar 2. Alat Pembakaran Ikan Tradisional 
2. Studi Pasar Pengguna

Pada tahap studi pasar pengguna ini kuesioner terbuka di sebarkan sebanyak 5 orang pedagang dan operator yang melakukan pembakaran ikan. Pekerja tersebut merupakan responden dalam penelitian ini. Kuesioner terbuka digunakan untuk mengetahui kelebihan dan kekurangan fitur alat pembakaran ikan tradisional yang telah ada. Serta digunakan juga untuk mengetahui peluang untuk pengembangan alat yang akan diberikan oleh peneliti.
3. Identifikasi Kebutuhan Pengguna

Tahapan mengidentifikasi kebutuhan pengguna dari hasil kuesioner terbuka yang disebarkan kepada 5 responden. Identifikasi kebutuhan pengguna bertujuan untuk mengetahui kebutuhan apa saja yang diinginkan oleh konsumen atau responden tersebut. Tabel 1 merupakan tabel daftar respon pengguna atau tabel pernyataan pengguna yang didapatkan dari hasil kuesioner terbuka.

Tabel 1. Daftar Pernyataan Pengguna

\begin{tabular}{ll}
\hline Pertanyaan & Pernyataan Pengguna \\
& Murah \\
& Kapasitas besar \\
& Mudah untuk dipindahkan \\
& Mudah untuk digunakan \\
& Mudah ketika mengalami kerusakan \\
& Membutuhkan tenaga untuk mengoperasikan \\
& Sering mengalami nyeri punggung dan lengan \\
& Proses pembakaran kurang bersih \\
& Asap pembakaran yang mengganggu \\
& Abu sisa pembakaran berterbangan mengganggu operator \\
& Panas langsung dirasakan operator \\
& Harga \\
& Masa pakai \\
& Kemudahan penggunaan \\
& Mudah dalam perawatan \\
& Keindahan alat \\
& Kapasitas lebih banyak \\
& Mengurangi penggunaan tenaga \\
& Murah \\
& Desain yang bagus \\
& Nyaman digunakan \\
& Alat menjaga kebersihan ikan
\end{tabular}

Pada Tabel 1 merupakan pernyataan terbuka yang dapat dikolaborasikan dengan hasil kuesioner Nordic body map yang berkaitan dengan keluhan. Analisis yang dilakukan dengan pertanyaan terbuka ini dilakukan dengan tujuan untuk menggali kebutuhan pelanggan secara kluas dan tidak terkotak atau terfokus pada pernyataan yang telah diberikan.

Beberapa aspek yang dimunculkan dari pengguna alat pembakaran ikan adalah terkait harga, masa pakai alat, kemudahaan penggunaan, desain, kemudahan untuk perawatan, dan lain sebagainya. 


\subsection{Analisis Keluhan dengan Nordic Body Map}

Setelah dilakukan analisis dengan pertannya pembuka, dilakukan analisis terkait pengalaman dari operator pembakaran ikan berdasarkan keluhan pada bagian tubuh tertentu. Keluhan ini dianalisis dengan menggunakan Nordic Body Map. Pada tahap ini peneliti melakukan wawancara secara langsung dengan operator dan menanyakan efek yang dirasakan setelah bekerja dengan posisi kerja menunjukkan hasil analisis postur tubuh operator menggunakan kuisioner Nordic Body Map.

Dari Gambar 3 dapat diketahui hasil analisis menggunakan kuisioner Nordic Body Map. Untuk bagian tubuh yang merasakan sangat sakit (D) adalah bagian tubuh leher atas, leher bawah, bahu kanan, lenga atas kanan, pinggang, lengan bawah kanan, siku kanan, pergelangan tangan kanan.

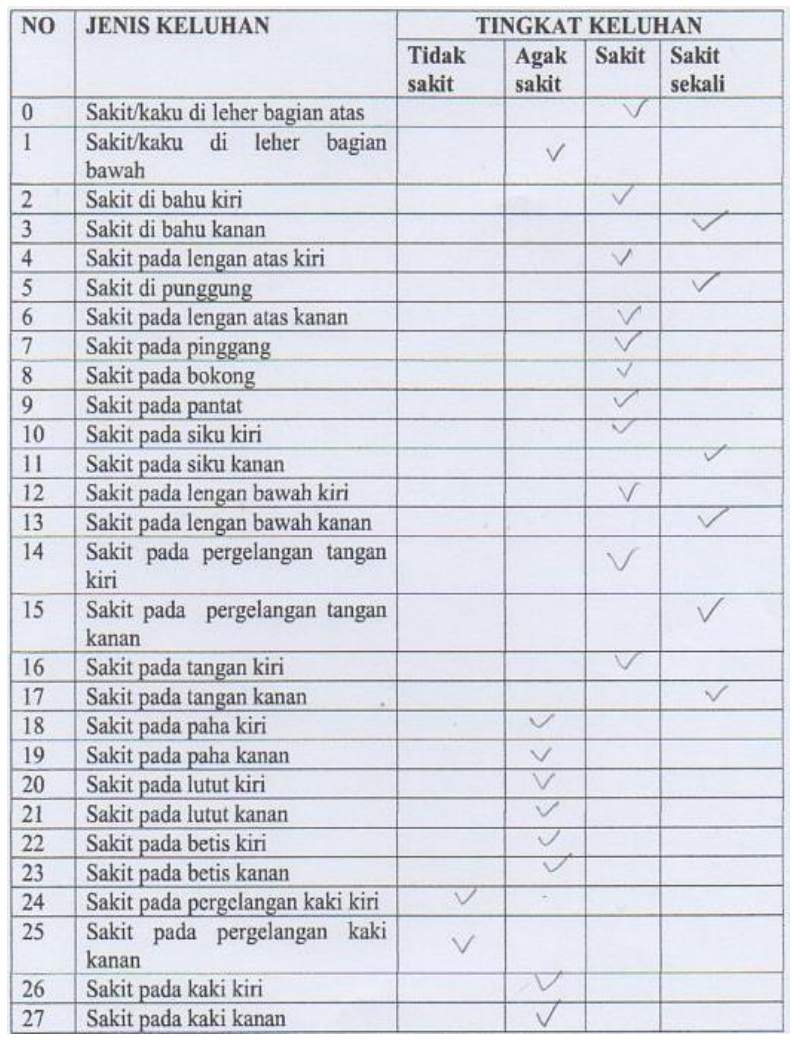

Gambar 3. Hasil Kuesioner Nordic Body Map untuk para pedagang ikan bakar

Untuk bagian tubuh yang terasa sakit (C) adalah lengan atas kiri, siku kiri, lean bawah kiri, pergelangan tangan kiri, tangan kiri, paha kiri dan kanan, betis kiri, betis kanan, kaki kanan dan kaki kiri.

Hasil analisis pada Nordic body map ini mendukung analisis postur kerja yang dilakukan menggnakan analisis rula sehingga dapat memberikan landasan didalam desain alat baru yang bersifat ergonomis.

\subsection{Perancangan Produk Alat Pembakaran Ikan}

\subsubsection{Kondisi sebelum perbaikan alat pembakaran ikan}

Pada proses pembakaran ikan dilakukan oleh operator dengan posisi yang dapat memunculkan terjadinya cedera. Posisi demikian tentu saja membuat operator sering merasakan nyeri ketika melakukan pekerjaannya dalam kurun waktu yang cukup 
lama. Selain itu dapat dilihat posisi meja yang terlau rendah mengakibatkan operator harus menekuk lutut lebih dari 90. Hal demikian juga mengakibatkan operator harus membungkuk sebesar ketika melakukan proses pembakaran ikan. Posisi demikian dilakukan operator selama \pm 7 jam setiap harinya membuat operator sering merasakan nyeri pada bagian bagian tubuh tertentu setelah bekerja. Gambar 4 menunjukkan foto alat pembakaran ikan sedangkan Gambar 5 menunjukkan postur kerja pada alat pembakaran ikan.

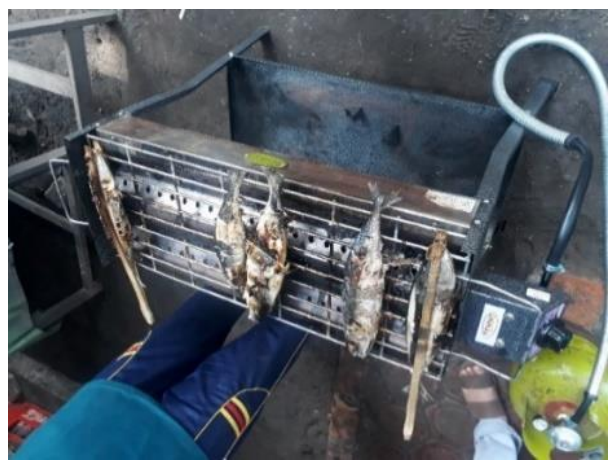

Gambar 4. Alat Pembakaran Ikan

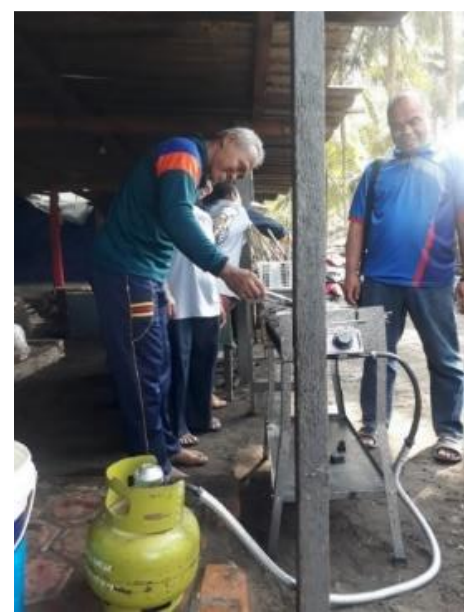

Gambar 5. Postur Kerja pada Alat Pembakaran Ikan

\subsubsection{Analisis postur kerja dengan RULA}

Metode RULA merupakan metode yang digunakan dalam melakukan analisis terhadap potensi dari postur tubuh operator yang hubungannya dengan cidera. Postur kerja yang dilakukan analisis saat ini adalah terkait postur kerja dari operator pembakar ikan di Pantai Pelang Trenggalek. Pada Gambar 6 dapat diketahui bahwa seorang operator sedang melakukan proses pembakaran ikan. Dari gambar tersebut akan dilakukan analisis terkait seberapa besar potensi cedera yang ada. Berikut penjelasan mengenai analisis menggunakan metode RULA.

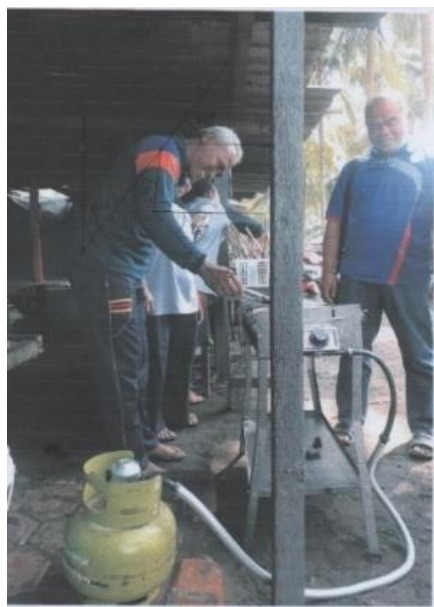

Gambar 6. Hasil Analisis Rula pada Postur Kerja Operator dengan Menggunakan Alat Kerja yang ada

Pengukuran yang dilakukan yaitu dengan cara mengukur besar sudut yang dibentuk oleh tubuh operator pada bagian atas. Untuk mengukur besar sudut yang dibentuk oleh operator, langkah pertama yang harus dilakukan yaitu dengan membuat garis lurus yang berada dibelakang operator dimana garis tersebut tegak lurus dengan posisi operator. Langkah kedua yaitu menarik garis yang sesuai dengan posisi tubuh bagian atas operator sampai bertemu dengan garis awal. Pada gambar diketahui besar sudut untuk tubuh bagian atas operator sebesar $37^{\circ}$. Langkah ketiga yaitu menarik garis dari garis kedua sampai garis ketiga, dimana garis ketiga sejajar dengan posisi lengan bagian atas operator. Sehingga dapat diketahui posisi lengan bagian atas operator 
pada Gambar 6 membentuk sudut sebesar $30^{\circ}$. Langkah keempat yaitu menarik garis dari garis ketiga sampai garis keempat. Garis keempat berada pada posisi sejajar dengan lengan bawah operator yang membentuk sudut sebesar $46^{\circ}$.

Setelah besar sudut yang terbentuk diketahui, maka langkah selanjutnya melakukan analisis postur tubuh operator tersebut. Analisis postur tubuh operator dilakukan dengan cara menyesuaikan antara postur tubuh operator pada saat bekerja dengan tabel penilaian metode RULA. Gambar 7 merupakan gambar analisis postur tubuh operator pembakaran ikan dengan tabel penilaian metode RULA.

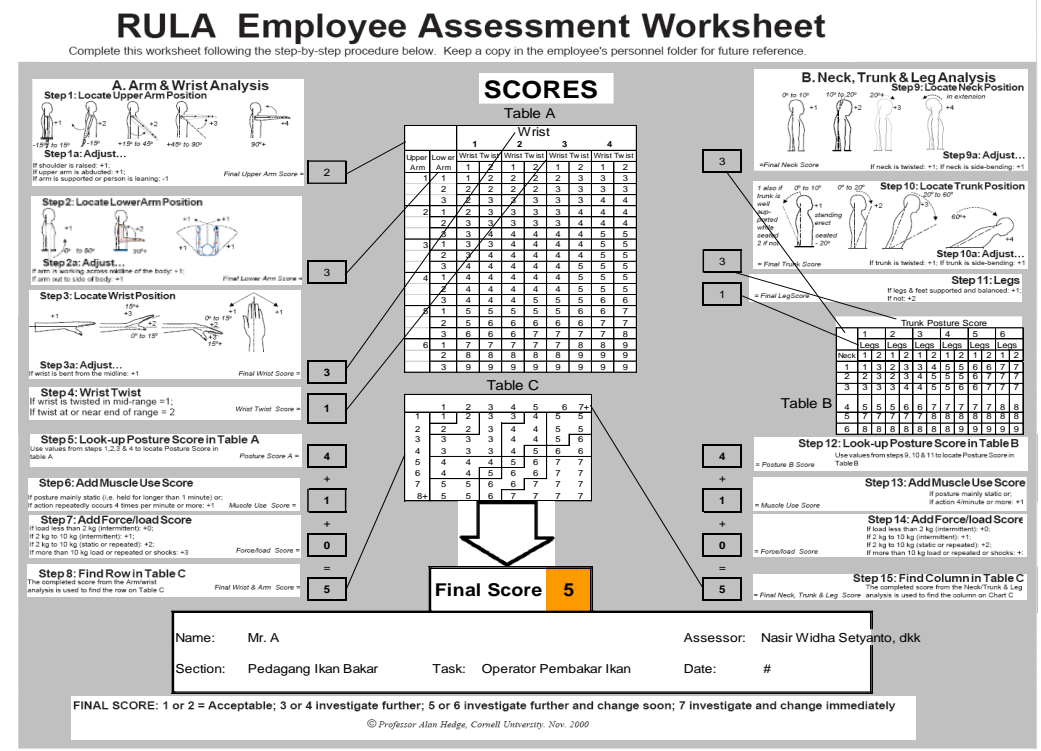

Gambar 7. Penilaian RULA awal

Tabel 3 merupakan penjelasan hasil analisis postur tubuh operator menggunakan metode RULA. Ada beberapa variabel yang dinilai untuk menganalisis potensi cedera dengan metode RULA, diantaranya: posisi lengan bagian atas, posisi lengan bagian bawah, posisi pergelangan tangan, jenis aktivitas yg dilakukan, berat beban yang dibawa, posisi leher, dan posisi tubuh bagian atas. Penilaian yang diberikan pada metode ini berupa skor. Skor yang diberikan harus disesuaikan dengan postur tubuh operator pada saat bekerja. Berikut merupakan penjelasan skor yang diberikan pada setiap step dengan metode RULA.

Setelah skor pada tiap bagian tersebut diketahui, maka dapat diketahui nilai akhir RULA. Skor akhir RULA didapatkan dengan melihat skor tabel $\mathrm{C}$ yaitu 5 yang menunjukkan bahwa postur pekerja gabungan dari analisis tubuh bagian atas operator yang terdiri dari leher, punggung, lengan atas, lengan bawah, pergelangan tangan yang memerlukan penelitian lebih lanjut dan perlu perbaikan langsung.

Tabel 3. Analisis Postur Tubuh Operator Pembakaran Ikan

\begin{tabular}{clrl}
\hline Step & Variabel & Skor & Penjelasan \\
\hline 1 & Lengan Atas & 2 & Posisi lengan atas \\
& & membentuk sudut \\
& & $30^{\circ}$, dapat \\
& & diartikan bahwa \\
& & sudut tersebut \\
& & terletak diantara \\
& & $45^{\circ}-90^{\circ}$ maka \\
& & diberikan skor 2. \\
& & & Posisi lengan \\
& & & bawah operator \\
& & & membentuk sudut \\
& & & $46^{0}$, angka \\
\hline & &
\end{tabular}




\begin{tabular}{|c|c|c|c|}
\hline Step & Variabel & Skor & Penjelasan \\
\hline 3 & Posisi tangan & 3 & $\begin{array}{l}\text { tersebut berada } \\
\text { diantara } 0^{\circ}-50^{\circ}, \\
\text { maka diberikan } \\
\text { skor } 2 \text {. Pada } \\
\text { postur yang sama } \\
\text { operator } \\
\text { melakukan } \\
\text { gerakan } \\
\text { menyilang } \\
\text { melebihi garis } \\
\text { tengah dari badan } \\
\text { operator maka } \\
\text { diberikan skor } 1 . \\
\text { Posisi tangan } \\
\text { operator } \\
\text { membentuk sudut } \\
\text { 390 } \text {, sehingga } \\
\text { diberikan skor } 3 \text {. }\end{array}$ \\
\hline 4 & $\begin{array}{l}\text { Pergelangan } \\
\text { Tangan }\end{array}$ & 1 & $\begin{array}{l}\text { Posisi } \\
\text { pergelangan } \\
\text { tangan operator } \\
\text { memutar sampai } \\
\text { garis tengah } \\
\text { tangan ketika } \\
\text { meletakkan ikan } \\
\text { pada pembakaran } \\
\text { maka diberikan } \\
\text { skor } 1 .\end{array}$ \\
\hline 5 & Skor Tabel A & 4 & $\begin{array}{l}\text { Skor } 4 \text { didapatkan } \\
\text { dari tabel A yang } \\
\text { ada di tabel } \\
\text { RULA dengan } \\
\text { melihat skor pada } \\
\text { step } 1-4 \text {. }\end{array}$ \\
\hline 6 & $\begin{array}{l}\text { Penggunaan } \\
\text { Otot }\end{array}$ & 1 & $\begin{array}{l}\text { Karena operator } \\
\text { melakukan } \\
\text { aktivitas kerja } \\
\text { yang static } \\
\text { selama }>10\end{array}$ \\
\hline 7 & Berat Beban & 0 & $\begin{array}{l}\text { Beban yang } \\
\text { dibawa oleh } \\
\text { operator }<4,4 \mathrm{lbs} \text {, } \\
\text { sehingga }\end{array}$ \\
\hline 8 & Skor Tabel C & 5 & $\begin{array}{l}\text { diberikan skor } 0 . \\
\text { Skor } 5 \text { diperoleh } \\
\text { dari hasil analisis } \\
\text { padaTabel A Rula }\end{array}$ \\
\hline 9 & Posisi Leher & 3 & $\begin{array}{l}\text { Posisi leher } \\
\text { operator } \\
\text { memberntuk } \\
\text { sudut } 55^{0} \text { dari } \\
\text { posisi tegak lurus } \\
\text { punggung. Maka } \\
\text { diberikan skor } 3 \text {. }\end{array}$ \\
\hline 10 & $\begin{array}{l}\text { Posisi Tubuh } \\
\text { Bagian atas }\end{array}$ & 3 & $\begin{array}{l}\text { Posisi tubuh } \\
\text { bagian atas } \\
\text { operartor } \\
\text { membungkuk ke } \\
\text { depan } \\
\text { membentuk sudut }\end{array}$ \\
\hline
\end{tabular}

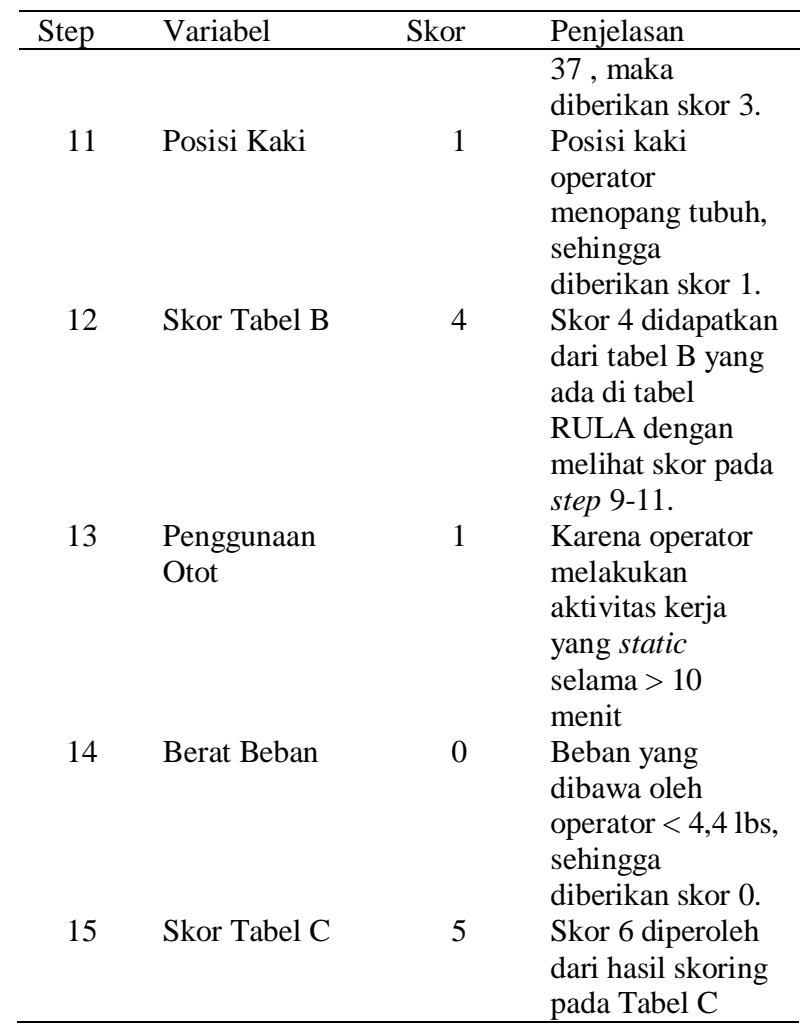

\subsubsection{Desain perbaikan alat pembakaran} ikan dengan antropometri

Dari hasil analisa postur tubuh operator ketika bekerja menggunakan metode RULA, maka dapat disimpulkan bahwa pada kondisi saat ini memerlukan adanya perbaikan untuk mengurangi potensi cedera operator. Ada beberapa cara untuk memperbaiki postur kerja operator tersebut, seperti melakukan perbaikan tata cara dalam melakukan pekerjaannya dan merancang alat bantu yang dapat mempermudah pekerjaan operator untuk mengurangi potensi cedera yang ada. Dalam penelitian ini akan dilakukan perancangan alat bantu yang dapat membantu pekerjaan operator serta mengurangi potensi cedera operator pada saat melakukan pekerjaannya. Data antropometri akan digunakan sebagai acuan untuk merancang alat pembakaran ikan. Penetepan dimensi tubuh operator digunakan untuk menetukan dimensi alat bantu yang bertujuan agar alat tersebut sesuai dengan 
penggunanya. Data antropometri yang dibutuhkan dari operator yaitu:

1. Panjang jangkauan tangan kedepan (D24)

2. Tinggi bahu dalam posisi duduk (D10)

3. Tebal paha (D12)

4. Lebar sisi bahu (D17)

5. Tinggi pinggul (D5)

Tabel 4 merupakan penjelasan penggunaan data antropometri yang digunakan beserta dengan fungsinya.

Tabel 4. Fungsi Data Antropometri

\begin{tabular}{|c|c|}
\hline Dimensi & Fungsi \\
\hline $\begin{array}{ll}\text { 1. } & \text { Panjang } \\
\text { jangkauan } \\
\text { tangan kedepan } \\
\text { (D24) }\end{array}$ & $\begin{array}{l}\text { Untuk menentukan } \\
\text { dimensi panjang alat } \\
\text { pembakaran }\end{array}$ \\
\hline $\begin{array}{l}\text { 2. Panjang lengan } \\
\text { atas (D22) }\end{array}$ & \\
\hline $\begin{array}{l}\text { 3. Lebar sisi bahu } \\
\text { (D17) }\end{array}$ & \\
\hline Tinggi pinggul (D5) & $\begin{array}{l}\text { Untuk menentukan } \\
\text { tinggi alat } \\
\text { pembakaran }\end{array}$ \\
\hline Panjang ikan & $\begin{array}{l}\text { Untuk menentukan } \\
\text { lebar alat pembakaran }\end{array}$ \\
\hline
\end{tabular}

Terdapat 4 klasifikasi yakni suku, jenis kelamin, tahun, dan usia. Pada kolom suku dipilih semua suku, hal ini ditujukan agar data yang digunakan untuk perancangan alat bantu dapat digunakan sesuai dengan ukuran seluruh masyarakat Indonesia. Selain itu pada kolom jenis kelamin juga dipilih semua jenis kelamin, hal ini juga ditujukan agar alat bantu yang akan dirancang dapat digunakan oleh operator pria atau wanita. Untuk kolom tahun dipilih 2 tahun terakhir, yakni mulai dari tahun 2016-2017. Untuk kolom usia dipilih antara usia 17 tahun sampai 40 tahun. Usia ini merupakan usia produktif manusia. Dari klasifikasi yang telah dipilih didapatkan data untuk tiap dimensi tubuh. Tabel 5 merupakan data antropometri yang digunakan untuk merancang alat pembakaran ikan.
Tabel 5. Data Antropometri Alat Pembakaran Ikan

\begin{tabular}{|c|c|c|c|c|c|}
\hline \multirow{2}{*}{ D } & \multirow{2}{*}{ Keterangan } & \multicolumn{3}{|c|}{ Persentil } & \multirow{2}{*}{ SD } \\
\hline & & 5 th & 50th & 95th & \\
\hline D5 & Tinggi pinggul & 84.82 & 94.51 & 104.21 & 5.9 \\
\hline D17 & $\begin{array}{l}\text { Lebar sisi } \\
\text { bahu }\end{array}$ & 29.68 & 39.38 & 49.07 & 5.89 \\
\hline D22 & $\begin{array}{l}\text { Panjang } \\
\text { lengan atas }\end{array}$ & 21.85 & 32.04 & 42.23 & 6.2 \\
\hline D24 & $\begin{array}{l}\text { Panjang } \\
\text { jangkauan } \\
\text { tangan } \\
\text { kedepan }\end{array}$ & 61.75 & 73.8 & 85.86 & 7.33 \\
\hline
\end{tabular}

Dari Tabel 5 dapat diketahui ukuran dimensi tubuh rata-rata penduduk di Indonesia pada persentil 5, 50 dan 95. Selain itu dapat diketahui juga besar standar deviasi pada tiap dimensi tubuh. Data-data tersebut digunakan untuk merancang alat bantu sehingga dapat sesuai dengan dimensi tubuh operator pembakaran ikan.

\subsubsection{Desain ergonomi}

Untuk merancang alat bantu diperlukan data yang sesuai dengan dimensi tubuh operator. Pada penelitian ini menggunakan data antropometri Indonesia dengan tujuan agar alat bantu yang dirancang dapat sesuai dengan ukuran rata-rata penduduk di Indonesia. Setelah melakukan pegukuran dimensi tubuh manusia, maka langkah selanjutnya yaitu melakukan perancangan desain alat bantu dengan mengacu pada pengukuran dimensi yang telah dilakukan sebelumnya. Alat bantu yang baru didesain untuk mengurangi risiko cedera operator ketika melakukan proses pembakaran ikan. Gambar 8 dan 9 merupakan gambar dari desain alat pembakaran yang baru beserta dimensinya. Desain untuk lebar dari alat pembakaran ikan didapatkan dari lebar rata-rata ikan yang dibakar. Sedangkan panjang dari alat pembakaran adalah melalui perhitungan sebagai berikut:

a. Penentuan dimensi jarak tangan secara diagonal ke samping tubuh operator dengan menghitung secara phitagoras 
pada dimensi D22 (panjang lengan atas $=32,04 \mathrm{~cm}$ ) dan D24 (panjang rentang lengan ke depan $=66,18 \mathrm{~cm})$

b. Setelah mendapatkan nilai diagonal ke samping dari tubuh operator $(57,9 \mathrm{~cm})$ maka selanjutnya dihitung nilai lebar jangkauan miring maksimum yang dapat dijangkau oleh tangan operator dengan cara phitagoras dengan sisi yang lain jarak tubuh operator ke panggangan (20 $\mathrm{cm})$

c. Didapatkan diagonal jangauan tangan operator ke samping dengan dikali dua pada nilai $54,34 \mathrm{~cm}$ dan dengan menambahkan D17 (lebar sisi bahu = $38,75 \mathrm{~cm}$ ) maka didapatkan dimensi 147,43 diberikan allowance maka didapatkan dimensi $150 \mathrm{~cm}$

\subsection{Analisis Hasil Perbaikan Postur Kerja}

Setelah dilakukan penentuan dimensi perbaikan alat pembakaran maka diperlukan untuk analisis postur kerja setelah dilakukan perbaikan pada alat pembakaran. Hasil analisis tersebut dilakukan pengukuran dengan metode Rula yang hasilnya didapatkan pada Gambar 11 dan 12.

Gambar 11 merupakan hasil pengukuran sudut dari postur kerja operator pembakaran yang mana sudut tersebut diukur pada posisi punggung, lengan atas, lengan bawah, pergelangan tangan, telapak tangan, leher, dan beban dari ikan yang di bakar. Tabel 6. merupakan analisis yang digunakan untuk melakukan pengisian pada Gambar 12.

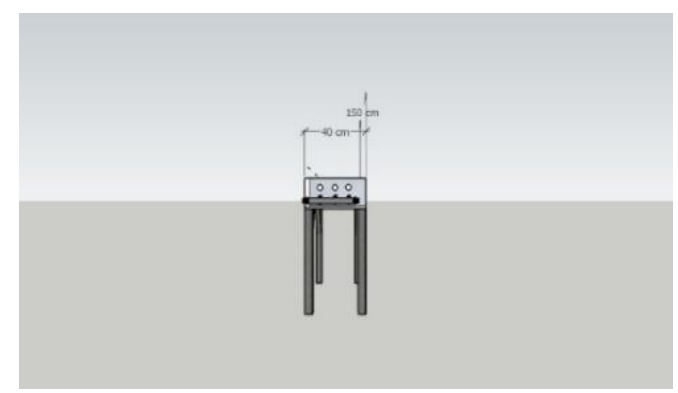

Gambar 8. Desain Alat Pembakaran Tampak Samping

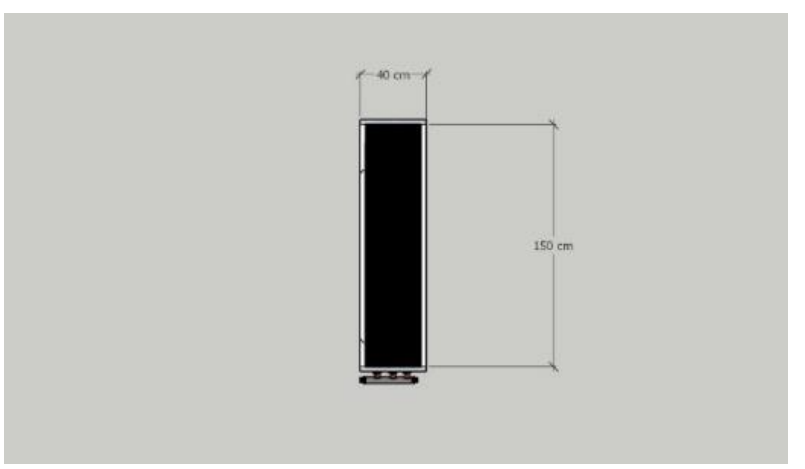

Gambar 9. Desain Alat Pembakaran Tampak Atas

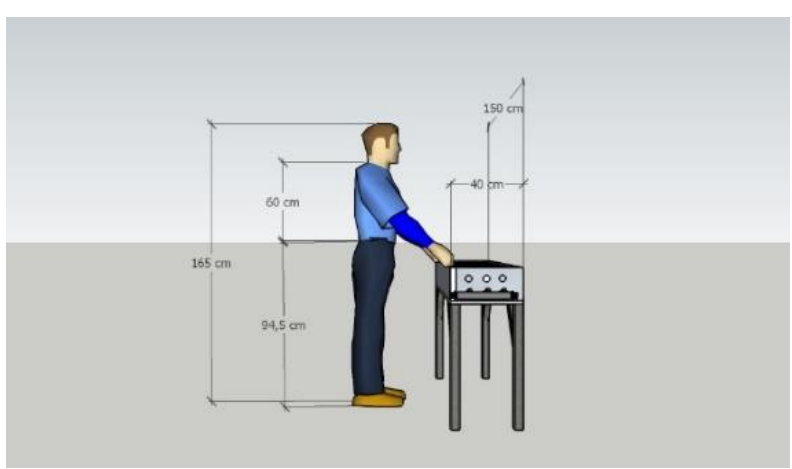

Gambar 10. Postur Operator Pembakaran Ketika Menggunakan Alat Pembakaran yang Telah Mengalami Perbaikan

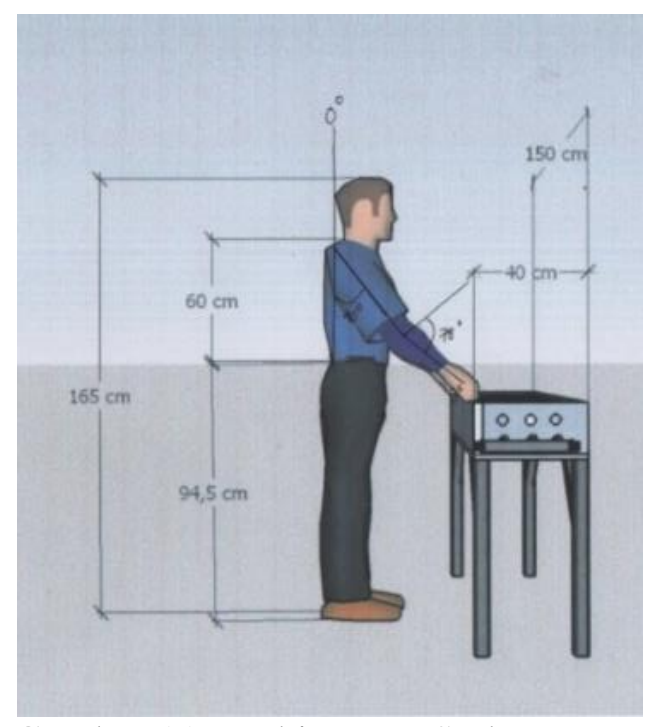

Gambar 11. Perhitungan Sudut Postur Operator Setelah Perbaikan 


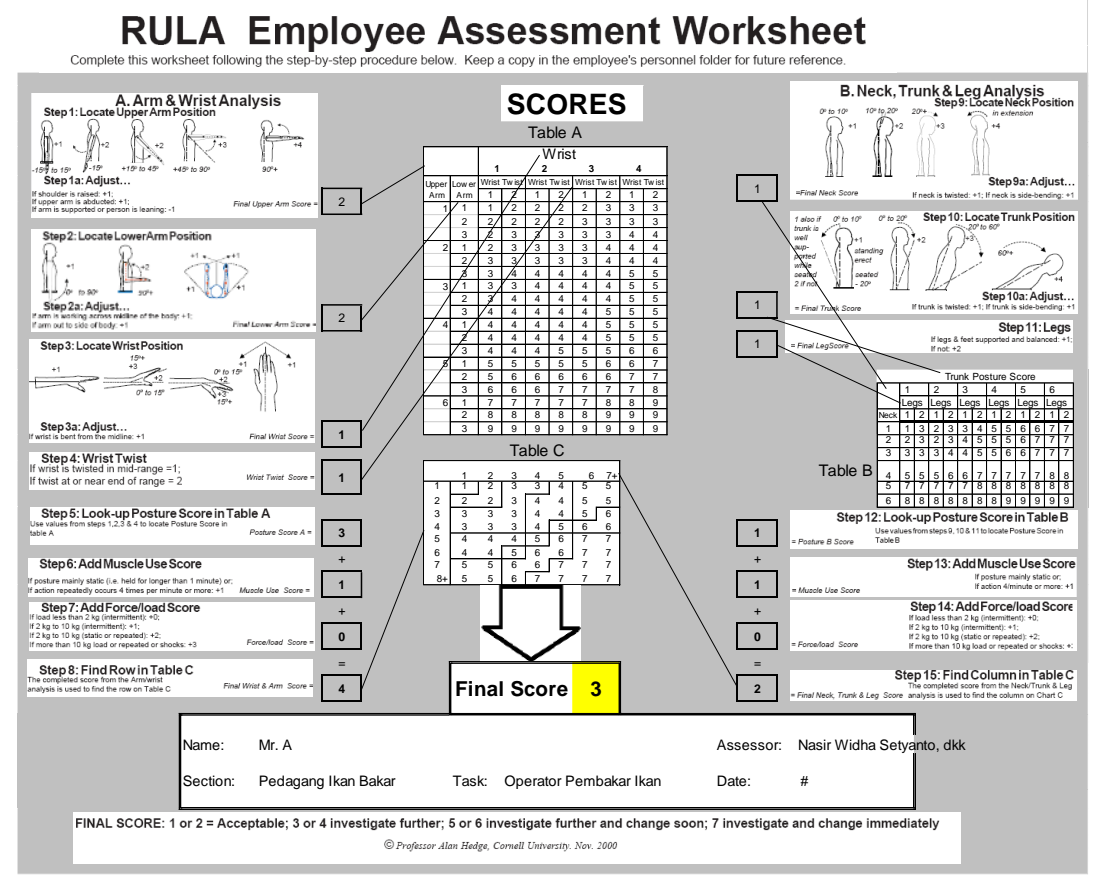

Gambar 12. Penilaian RULA Perbaikan

\begin{tabular}{|c|c|c|c|}
\hline Step & Variabel & Skor & Penjelasan \\
\hline 1 & Lengan Atas & 2 & $\begin{array}{l}\text { Posisi lengan atas } \\
\text { membentuk sudut } \\
40^{\circ} \text {, dapat } \\
\text { diartikan bahwa } \\
\text { sudut tersebut } \\
\text { terletak diantara } \\
45^{\circ}-90^{\circ} \text { maka } \\
\text { diberikan skor } 2 .\end{array}$ \\
\hline 2 & Lengan Bawah & $1+1$ & $\begin{array}{l}\text { Posisi lengan } \\
\text { bawah operator } \\
\text { membentuk sudut } \\
75^{\circ} \text {, angka } \\
\text { tersebut berada } \\
\text { diantara } 0^{\circ}-50^{\circ}, \\
\text { maka diberikan } \\
\text { skor } 2 \text {. Pada } \\
\text { postur yang sama } \\
\text { operator } \\
\text { melakukan } \\
\text { gerakan } \\
\text { menyilang } \\
\text { melebihi garis } \\
\text { tengah dari badan } \\
\text { operator maka } \\
\text { diberikan skor } 1 .\end{array}$ \\
\hline 3 & Posisi tangan & 1 & $\begin{array}{l}\text { Posisi tangan } \\
\text { operator } \\
\text { membentuk sudut } \\
0^{0} \text {, sehingga } \\
\text { diberikan skor } 1 \text {. }\end{array}$ \\
\hline
\end{tabular}

\begin{tabular}{|c|c|c|c|}
\hline Step & Variabel & Skor & Penjelasan \\
\hline 4 & $\begin{array}{l}\text { Pergelangan } \\
\text { Tangan }\end{array}$ & 1 & $\begin{array}{l}\text { Posisi } \\
\text { pergelangan } \\
\text { tangan operator } \\
\text { memutar sampai } \\
\text { garis tengah } \\
\text { tangan ketika } \\
\text { meletakkan ikan } \\
\text { pada } \\
\text { pembakaran, } \\
\text { maka diberikan } \\
\text { skor } 1 .\end{array}$ \\
\hline 5 & Skor Tabel A & 4 & $\begin{array}{l}\text { Skor } 4 \\
\text { didapatkan dari } \\
\text { tabel A yang ada } \\
\text { di tabel RULA } \\
\text { dengan melihat } \\
\text { skor pada step 1- } \\
4 \text {. }\end{array}$ \\
\hline 6 & $\begin{array}{l}\text { Penggunaan } \\
\text { Otot }\end{array}$ & 1 & $\begin{array}{l}\text { Karena operator } \\
\text { melakukan } \\
\text { aktivitas kerja } \\
\text { yang static } \\
\text { selama > } 10\end{array}$ \\
\hline 7 & Berat Beban & 0 & $\begin{array}{l}\text { Beban yang } \\
\text { dibawa oleh } \\
\text { operator }<4,4 \\
\text { lbs, sehingga } \\
\text { diberikan skor } 0 .\end{array}$ \\
\hline 8 & Skor Tabel C & 4 & $\begin{array}{l}\text { Skor } 5 \text { diperoleh } \\
\text { dari hasil analisis } \\
\text { padaTabel A } \\
\text { Rula }\end{array}$ \\
\hline
\end{tabular}




\begin{tabular}{|c|c|c|c|}
\hline Step & Variabel & Skor & Penjelasan \\
\hline 9 & Posisi Leher & 1 & $\begin{array}{l}\text { Posisi leher } \\
\text { operator } \\
\text { memberntuk } \\
\text { sudut } 55^{0} \text { dari } \\
\text { posisi tegak lurus } \\
\text { punggung. Maka } \\
\text { diberikan skor } 3 \text {. }\end{array}$ \\
\hline 10 & $\begin{array}{l}\text { Posisi Tubuh } \\
\text { Bagian atas }\end{array}$ & 1 & $\begin{array}{l}\text { Posisi tubuh } \\
\text { bagian atas } \\
\text { operartor } \\
\text { membungkuk ke } \\
\text { depan } \\
\text { membentuk sudut } \\
37 \text {, maka } \\
\text { diberikan skor } 3 \text {. }\end{array}$ \\
\hline 11 & Posisi Kaki & 1 & $\begin{array}{l}\text { Posisi kaki } \\
\text { operator } \\
\text { menopang tubuh, } \\
\text { sehingga } \\
\text { diberikan skor } 1 .\end{array}$ \\
\hline 12 & Skor Tabel B & 1 & $\begin{array}{l}\text { Skor } 4 \\
\text { didapatkan dari } \\
\text { tabel B yang ada } \\
\text { di tabel RULA } \\
\text { dengan melihat } \\
\text { skor pada step 9- } \\
11 .\end{array}$ \\
\hline 13 & $\begin{array}{l}\text { Penggunaan } \\
\text { Otot }\end{array}$ & 1 & $\begin{array}{l}\text { Karena operator } \\
\text { melakukan } \\
\text { aktivitas kerja } \\
\text { yang static } \\
\text { selama }>10 \\
\text { menit }\end{array}$ \\
\hline 14 & Berat Beban & 0 & $\begin{array}{l}\text { Beban yang } \\
\text { dibawa oleh } \\
\text { operator }<4,4 \\
\text { lbs, sehingga } \\
\text { diberikan skor } 0 \text {. }\end{array}$ \\
\hline 15 & Skor Tabel C & 3 & $\begin{array}{l}\text { Skor } 6 \text { diperoleh } \\
\text { dari hasil skoring } \\
\text { pada Tabel C }\end{array}$ \\
\hline
\end{tabular}

Hasil perngukuran pada metode rula sebelum dan sesudah perbaikan kita perbandingkan pada Tabel 7. yang menunjukkan penurunan nilai 5 ke 3 . Hal ini dikarenakan setelah dilakukan perbaikan pada dimensi alat pembakaran didapatkan perbaikan postur pada punggung, leher, dan telapak tangan.

Berdasarkan analisis yang dilakukan pada Tabel 7 berupa perbandingan kondisi sebelum perbaikan desain dan sesudag perbaikan desain dapat diestimasi bahwa terjadi penurunan skor pada 4 postur bagian tubuh, diantaranya adalah: lengan bawah, pergelangngan tangan, leher, punggung. Hal ini ketika dilakukan analisis skor RULA gabungan didapatkan penurunan nilai dari 5 menjadi 3 .

Tabel 7. Perbandingan Skore RULA untuk Sebelum dan Sesudah Perbaikan

\begin{tabular}{clcc}
\hline No & \multicolumn{1}{c}{ Postur } & $\begin{array}{c}\text { Sebelum } \\
\text { Perbaikan }\end{array}$ & $\begin{array}{c}\text { Setelah } \\
\text { Perbaikan }\end{array}$ \\
\hline 1 & Lengan atas & 2 & 2 \\
2 & $\begin{array}{l}\text { Lengan } \\
\text { bawah }\end{array}$ & 2 & 1 \\
3 & $\begin{array}{l}\text { Pergelangan } \\
\text { Tangan }\end{array}$ & 3 & 1 \\
4 & Leher & 3 & 1 \\
5 & Punggung & 3 & 1 \\
6 & Skore RULA & 5 & 3 \\
\hline
\end{tabular}

\section{Kesimpulan}

Analisis yang dilakukan pada permasalahan yang dihadapi oleh pedagang pada proses pembakaran ikan terkait penggunaan alat pembakaran ikan adalah dirasakan keluhan pada bagian tubuh yang merasakan sangat sakit adalah bagian tubuh leher atas, leher bawah, bahu kanan, lenga atas kanan, pinggang, lengan bawah kanan, siku kanan, pergelangan tangan kanan. Untuk bagian tubuh yang terasa sakit adalah lengan atas kiri, siku kiri, lean bawah kiri, pergelangan tangan kiri, tangan kiri, paha kiri dan kanan, betis kiri, betis kanan, kaki kanan dan kaki kiri.

Desain alat untuk membakar ikan sehingga dapat meningkatkan kualitas hasil pembakaran terhadap ikan adalah dengan menggunakan dimensi antropometri pada D5 yang digunakan untuk menentukan tinggi dari alat pembakaran $(87,3 \mathrm{~cm})$ kemudian penentuan lebar adalah dengan menggunakan panjang ikan yang dibakar $(40 \mathrm{~cm})$, sedangkan lebar alat pembakaran $150 \mathrm{~cm}$ 
dengan menggunakan dimensi panjang lengan atas (D22), panjang jangkauan tangan ke depan (D24), dan lebar sisi bahu (D17).

Kemanfaatan alat terhadap permasalahan yang dihadapi oleh pedagang adalah menurunnya resiko cedera atau kelelahan yang didapatkan operator dengan indicator skor nilai RULA yang sebelum perbaikan adalah 5 dan setelah perbaikan adalah 3 yang artinya adalah diperlukan perbaikan.

\section{Daftar Pustaka}

Ardiliansyah, R. R., Handoko, L., Wiedartini. (2017). Analisis Tingkat Risiko Cedera MSDs pada Pekerjaan Manual Material Handling dengan Metode REBA dan RULA pada Pekerjaan Area Produksi Butiran PT. Petrokimia Kayaku. Proceeding 1st Conference on Safety Engineering and Its Application, 61-66.

Chen, J., Falkmer, T., Parsons, R., Buzzard, J., \& Ciccarelli, M. (2014). Impact of experience when using the Rapid Upper Limb Assessment to assess postural risk in children using information and communication technologies. Applied Ergonomics, 45(3), 398-405.

Dockrell, S., O’Grady, E., Bennett, K., Mullarkey, C., Mc Connell, R., Ruddy, R., ... Flannery, C. (2012). An investigation of the reliability of Rapid Upper Limb Assessment (RULA) as a method of assessment of children's computing posture. Applied Ergonomics, 43(3), 632-636.

Hardianto, H., Hardianto, H., Ardiasandy, A., Henny. (2018). Analisis Postur Tubuh Pekerja Menggunakan Nordic Dan RULA. Inaque Vol. 6 No. 2 AGUSTUS 2018, 91-96.
Manghisi, V., Uva, A., Fiorentino, M., Bevilacqua, V., Trotta, G., \& Monno, G. (2017). Real time RULA assessment using Kinect v2 sensor. Applied Ergonomics, 65, 481-491.

McAtamney, L. Y Corlett, E. N., (1993). RULA: A survey method for the investigation of work-related upper limb disorders. Applied Ergonomics, 24, pp. 91-99.

Oesman,T. I., Irawan, E., Wisnubroto, P. (2019). Analisis Postur Kerja dengan RULA Guna Penilaian Tingkat Risiko Upper Extremity Work-Related Musculoskeletal Disorders Studi Kasus PT. Mandiri Jogja Internasional. Jurnal Ergonomi Indonesia Vol. 05 No.01 Tahun 2019, 39-46.

Roman-Liu, D. (2014). Comparison of concepts in easy-to-use methods for MSD risk assessment. Applied Ergonomics, 45(3), 420-427.

Sari, R., \& Swara, S. (2014). Analisis Penggunaan Bangku Sekolah Ukuran Fixed Dan Adjustable Untuk Anak Sekolah Dasar. Journal of Engineering and Management in Industrial System, 2(1). doi:http://dx.doi.org/ 10.21776/ub. jemis.2014.002.01.7

Sugiono, S., Soenoko R., Lukodono R.P. (2017). A Designing Dairy Cattle Facilties Based On Statics/Dynamic Zoometry by Using Artificial Intelligence.TELKOMNIKA

(Telecommunication, Computing, Electronics and Control) 2017 15(1), 399-406.

Sugiyono. (2012). Metode Penelitian Kuantitatif Kualitatif dan R\&D. Bandung:Alfabeta 